\title{
PROTEROZOIC PROGRESS TO MEGASCOPIC COMPLEXITY
}

\author{
RUNNEGAR, Bruce, Department of Earth and Space Sciences \\ University of California, Los Angeles, CA 90095-1567, U.S.A.
}

Paleontological evidence for the existence of animals as complex as Halkieria evangelista by the earliest Cambrian shows that the "Big Bang" of animal evolution was well underway by the end the Proterozoic. If phylogenetic trees based on 18S rRNAs are even approximately correct, most of the extant animal phyla have invisible roots in the Neoproterozoic and must have coexisted with the problematical organisms of the Ediacara "fauna".

Recent discoveries in Nevada and Namibia have taken core members of the Ediacara "fauna" to the end of the Proterozoic, thus closing the stratigraphic gap (Kotlin interval) that had been assumed to separate the Ediacaran biota from the Cambrian explosion. The times of origin of the Ediacaran organisms and the animal phyla remain unknown but independent $\mathrm{U}-\mathrm{Pb}$ dates on the ash bed that covered an already diverse Ediacaran assemblage at Mistaken Point, Newfoundland, are approximately 20 million years older than the base of the Cambrian. An argument based on the resolution of nodes in rRNA trees may be used to suggest a significantly longer Precambrian history for the Metazoa, but the first metazoan trace fossils are no older than about 550 million years.

Key questions concerning the nature of the Ediacaran organisms remain unresolved but there is good morphologic and taphonomic evidence for the presence of several major clades (fronds, petalonamans, trilobozoans, etc.), that are uncomfortably united in Seilacher's extinct kingdom, the Vendobionta. Furthermore, old misconceptions are being discarded as we learn more about these enigmatic organisms from recent discoveries in Namibia, Newfoundland, Nevada, and South Australia.

Few, if any, of the Ediacaran organisms belong to the crown groups of animal phyla, none were cnidarian jellyfish, and some of the best known forms (Dickinsonia, Ernietta, Phyllozoon, Pteridinium) are difficult to place in any extant animal or plant group. However, even these "core vendobionts" differ significantly from each other in the fundamental properties of construction, growth, mode of preservation, and symmetry.

Together with the associated carbonate skeletons and trace fossils, the Ediacaran organisms provide a glimpse of biodiversity at the close of the Proterozoic. It is the synchronous appearance of distantly related clades of megascopic organisms that points to the poverty of intrinsic versus extrinsic explanations for the nature of the Cambrian explosion of multicellular life.

The terminal Proterozoic prelude to the Cambrian explosion stands in stark contrast to the limited fossil record of sizeable organisms during the preceding two billion years of Proterozoic time. However, there is good evidence for the existence of a variety of megascopic algae, including distinctive taxa such as Grypania and Longfengshania, from rocks younger than about 1.8 billion years. New data from India shows that Grypania was probably cellular rather than coenocytic, thus increasing the probability that it is a crown group eukaryote. This discovery makes the two billion delay in algal diversification one of the unexplained puzzles of Proterozoic life. 